\title{
COMPLIANCE CHARACTERISTICS OF COMMUNITY HEALTH ASSISTANT CADRE IN IMPLEMENTING HEALTH PROTOCOLS DURING COVID-19 PANDEMIC
}

\author{
Sri Wahyuningsih, Hany Yusmaini, Erna Harfiani, Meiskha Bahar
}

Faculty of Medicine, UPN Veteran Jakarta

\begin{abstract}
Background: Covid-19 is a highly infectious disease. Primary prevention approaches, including personal protective measures, social distancing, and environmental surface cleaning, are required to contain disease transmission. This study aimed to investigate the compliance in implementing Covid-19 health protocols among cadres at Community Health Centre, Depok, West Java.

Subjects and Method: This was a descriptive cross-sectional study conducted at Community Health Centre, Depok, West Java. A total of 73 cadres was selected for this study. The study variables were compliance on Covid-19 protocols, including maskwearing, hand hygiene, physical and social distancing, level of education, level of Covid-19 knowledge, and other personal risk factors. The study subjects were selected by total sampling. The primary data were collected via WhatsApp group using questionnaires. The data were reported descriptively.

Results: Two-third of study subjects were at age 40-50 years (61.64\%). The majority of subjects were junior high school educational level (74.4\%). All the study subjects complied to wear a face mask (100\%). The majority of cadres possessed a high level of Covid-19 knowledge (57.53\%). Most of the cadres were unemployment (72.88\%). The common personal health problem was digestive problems (10.96\%).

Conclusion: The characteristics of cadres vary with age, educational level, level of compliance in Covid-19 protocols, work status, and level of Covid-19 knowledge. The common personal health problem among cadres is digestive problems.
\end{abstract}

Keywords: compliance, Covid-19, health protocols, characteristics

Correspondence:

Sri Wahyuningsih. Faculty of Medicine, UPN Veteran Jakarta. Jl. Pondok Labu, Jakarta Selatan. Email: dr_sriwahyuningsih@yahoo.com. Mobile: +6281287552465. 